\title{
Persons with disabilities, cancer screening and related factors
}

\author{
Pessoas com deficiência, exames preventivos de câncer \\ e fatores relacionados
}

Shamyr Sulyvan de Castro ${ }^{1}$

Alarcos Cieza ${ }^{2}$

Chester Luiz Galvão Cesar ${ }^{3}$

${ }^{1}$ Physiotherapy

Department, Health

Sciences Center,

Universidade Federal do

Triângulo Mineiro. R.

Capitão Domingos 309,

Abadia. 38.025-010

Uberaba MG Brasil.

shamyrsulyvan@gmail.com

${ }^{2}$ Institute for Health and

Rehabilitation Sciences,

Research Unit for

Biopsychosocial Health,

Ludwig-Maximilian

University, Munich.

${ }^{3}$ Epidemiology

Department, Faculdade de

Saúde Pública, USP.

\begin{abstract}
The scope of this article is to describe persons with disabilities (PwD) being subjected to cancer screening and the relationship between some social variables and inequalities in performing these tests. A cross-sectional study of cancer screening among PwD was conducted in 2007 with 333 participants interviewed in residence in 4 cities of São Paulo. Variables in the practice of cancer screening, disabilities, gender, age, income of main family breadwinner, ethnicity, use of health services, assistance required, private health insurance, and coverage by the family health program were studied. Frequencies, $\chi^{2}$-test, trend $\chi^{2}$ percentages and the Odds Ratios (OR) were used for data analysis. 44\% of PwD attended at least one cancer screening at the appropriate time. Persons with visual disabilities and with hearing disabilities were subjected to more screening examinations than those with mobility disabilities and women were attended in screening exams more than men. Persons between the ages of 21 and 60 reported cancer screening more frequently than those between 80 and 97 years of age. The outcomes indicate that PwD have different attitudes toward cancer screening according to the type of disability, gender, and age, which were the variables that directly influenced cancer screening exams.
\end{abstract}

Key words Persons with disabilities, Early cancer detection, Health surveys
Resumo O objetivo deste artigo é descrever a realização de exames preventivos de câncer entre pessoas com deficiências (PD) e a relação entre algumas variáveis sociais $e$ as desigualdades na realização dos exames. Estudo transversal sobre exames preventivos de câncer entre PD. Foram entrevistadas em domicílio 333 pessoas em quatro cidades de São Paulo, em 2007. Estudou-se variáveis relacionadas aos exames preventivos, deficiências, gênero, idade, renda do chefe da família, etnia, uso de serviços de saúde, assistência necessária, plano privado de saúde e cobertura pela Estratégia de Saúde da Família. Para a análise usou-se frequências, porcentagens, teste de $\chi^{2}, \chi^{2}$ de tendência e Odds Ratio (OR). Dos entrevistados, $44 \%$ realizou pelo menos um exame preventivo na época correta. Pessoas com deficiência visual e com deficiência auditiva fizeram mais exames do que aqueles com deficiência física. Mulheres fizeram mais exames que os homens e pessoas com idade entre 21 e 60 anos relataram maior frequência de exames que aquelas entre 80 e 97 anos. Os achados indicam que as PD tiveram diferentes padrões de realização de exames preventivos segundo o tipo de deficiência, gênero e idade, sendo estas as variáveis de influência direta na realização de exames preventivos de câncer.

Palavras-chave Pessoas com deficiência, Detecção precoce de câncer, Inquéritos de saúde 


\section{Introduction}

The incidence of cancer has increased worldwide ${ }^{1}$. In São Paulo city, the cancer disease were the sixth cause of hospitalization in 2011 (6.22\% of all hospital admissions $)^{2}$ and the second major cause of death in 2009 ( $14.9 \%$ of all death were caused by cancer $)^{3}$. Considering this scenario the prevention and control of the oncological diseases is indispensable and requires a multidisciplinary approach, including the cancer screening exams $s^{4}$, which are recommended according to the gender and age. In Brazil, the women should perform the Pap smear exam older than 24 years old or with the beginning of the sexual life, according to the WHO suggestion ${ }^{5}$; mammography for those over 39 years $^{6}$; the perform and age that the men should made a prostate screening exam (rectal touch, PSA dosage, biopsy, ultrasound) is not clear but this procedure is used is many countries ${ }^{7}$; and rectal screening cancer exam (fecal occult blood testing and colonoscopy) is suggested to all persons over 49 years old ${ }^{8}$.

The population group of the persons with disabilities are generally more vulnerable to further diseases ${ }^{9,10}$ and often have more difficulty using health services ${ }^{11}$. In the US, people with disabilities attended cancer screening services less frequently than those without disabilities ${ }^{12}$. The knowledge about the perform of the screening cancer exams among persons with disabilities and some related variables may improve the delivery of health services to these persons and lead to the early detection and treatment of cancer in this population group.

The objective of this research was to describe the frequency with which cancer screening is performed among a group of persons with disabilities and to what extent these data are related to selected social variables.

\section{Methods}

\section{Study Design}

The AceSS Study (Accessibility of Health Services to Persons with Disabilities) is a cross-sectional study of health and accessibility to health services among persons with disabilities and was carried out in Itapecerica da Serra, Embu, Taboão da Serra and São Paulo, 2007, all cities are located in the metropolitan area of São Paulo.

\section{Study Sample}

The original sample consisted of members of the general population participating in two other population-based health surveys conducted in the same city in 2001 and $2003^{13}$. From these two studies, 669 (age ranged 21 to 97 years old) persons who reported visual, hearing or mobility disabilities were selected. Visual disabilities include low vision, partial vision, and total blindness; hearing disabilities include low, partial, and complete hearing loss, mobility disabilities include paralysis and amputation of limbs or part of them. Four subgroups were formed: visual, hearing, mobility and multiple disabilities. How the final sample was obtained is described in Figure 1.

\section{Data Collection}

Data were collected by personal household interviews using a semi-structured questionnaire specially created for this survey. Different blocks of questions were provided for each of the four disability types. A block concerning cancer screen-

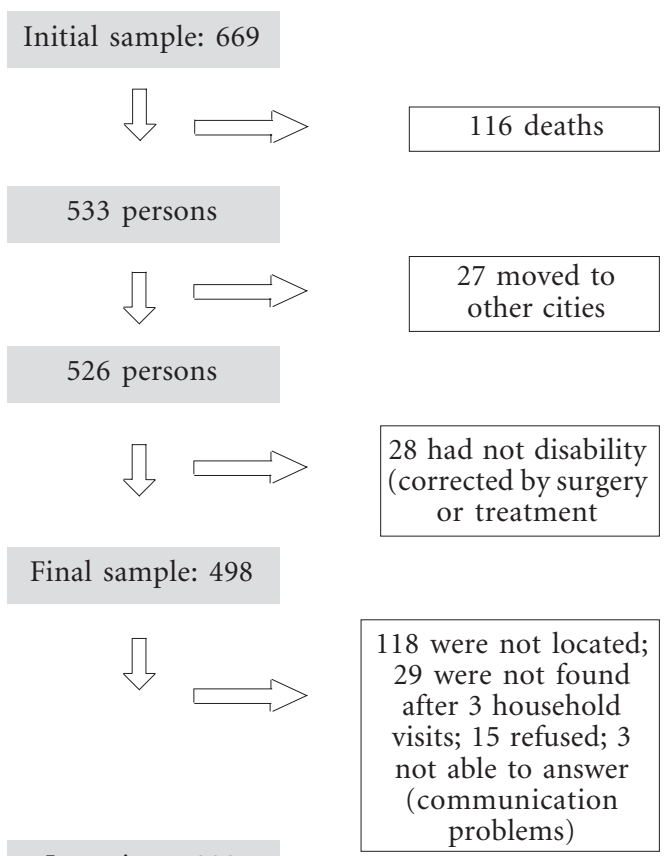

Interviews: 333

Figure 1. Description of the process of obtaining the final sample and interviews, AceSS, São Paulo, 2007. 
ing was contained in all questionnaires, regardless of the disability.

This study was approved by the Ethics Committee of the Public Health Faculty, University of São Paulo, and all participants signed an informed consent form.

\section{Analysis}

\section{Data Preparation}

The item about participating in cancer screening is dichotomous. When at least one of the following screening procedures was performed on the persons in the respective age and gender group, the answer to this variable was considered affirmative (exam performed):

1. Pap smear for women over 19 years.

2. Mammography for women over 39 years.

3. Prostate exam (rectal touch, PSA dosage, ultrasound, biopsy) for men over 39 years.

4. Rectal cancer screening (fecal occult blood testing and colonoscopy) for women and men over 39 years.

If persons were not in the specified age range for the screening procedure, their data were deleted from the database.

\section{Statistical Analysis}

Descriptive statistics were used to analyze the frequencies with which the cancer screening procedures were performed on persons with disabilities. The number and percentages of persons from the four subsamples who participated in screening were related to demographic and health-service variables. Differences among subsamples according to categorical variables were calculated using the $\chi^{2}$-test, and $\chi^{2}$-test for trend was used when there were more than two categories for a variable, and a linear trend between the variables was assumed.

The relationship between attending cancer screening and social variables was explored by logistic regression analyses. In the field of epidemiology, logistic regression describes the relationship between an outcome (dependent variable or response) and a simultaneous set of explanatory variables (predictors or independent variables) using a model that has good fit (biologically plausible and conforms to the principle of parsimo$n y)^{14}$. Whether the exam was performed or not was the dependent variable and social factors and health-service variables were studied as indepen- dent variables. A bivariate logistic regression model was subsequently fitted with the dependent variable and each of the independent variables. Finally, the full logistic regression model was fitted using the stepwise backward selection, i.e., we progressed from a complex model to a more simple one, deleting the variables according to the significance level $(p>0.20)$. In the final regression model, the variables family head's income, private health insurance, and assistance required were identified as confounding variables because when they were in the model, they changed the Odds Ratio (OR) of other variables. They had a statistical significance between 5\% and $20 \%$. The confounding variables were only kept in the final model for adjustment.

The statistical significance adopted was 5\%. Stata 9.2 was the statistical software used.

\section{Results}

Three hundred thirty-three persons with disabilities from a total of 498 disabled individuals were interviewed, resulting in a response rate of $67 \%$. The analyses were eventually performed for 297 persons because 36 were not in the appropriate age range for cancer screening. Table 1 describes the sample according to the variables studied.

According to the analyzed data, $44.44 \%$ of the interviewed population participated in at least one cancer screening during the study period; $61.11 \%$ and $53.52 \%$ women had a Pap smear and mammography, respectively; $75.94 \%$ men participated in prostate screening; and $13.00 \%$ of all interviewed persons participated in rectal screening.

The smallest percentage of screening exams was recorded in persons with multiple disabilities (13.67\%). Persons with visual disabilities had more screening exams than persons with other disabilities (55.17\%), while $41.86 \%$ of those with hearing disabilities participated in screening, and $39.73 \%$ persons with multiple disabilities had the same exams. Women participated in cancer screening significantly more frequently $(71.60 \%)$ than men (11.85\%). Persons aged between 21 and 60 years more frequently participated in screening (66.67\%), and persons between 74 and 79 years had the smallest percentage of cancer-screening procedures $(30.15 \%)$.

Analyses of family head's income showed that cancer screening is performed more frequently among those who belong to families whose heads earn between 2 and 5 times the monthly minimum wage (50\%). The group with less frequent 
Table 1. Demographic characteristics of participants and variables studied in cancer screening, AceSS, São Paulo, 2007.

\begin{tabular}{|c|c|c|c|c|c|c|c|}
\hline \multirow[b]{3}{*}{ Variables } & \multicolumn{7}{|c|}{ Preventive cancer exams } \\
\hline & \multicolumn{2}{|c|}{ No } & \multicolumn{2}{|c|}{ Yes } & \multicolumn{2}{|c|}{ Total } & \multirow[b]{2}{*}{$\mathbf{P}$} \\
\hline & $\begin{array}{c}\mathbf{n} \\
(165)\end{array}$ & $\begin{array}{c}\% \\
(55.56)\end{array}$ & $\begin{array}{c}\mathbf{n} \\
(132)\end{array}$ & $\begin{array}{c}\% \\
(44.44)\end{array}$ & $\begin{array}{c}\mathbf{n} \\
(297)\end{array}$ & $\begin{array}{c}\% \\
(100.00)\end{array}$ & \\
\hline \multicolumn{8}{|l|}{ Disability } \\
\hline Visual & 52 & 44.83 & 64 & 55.17 & 116 & 100.0 & $<0.01^{\mathrm{a}}$ \\
\hline Hearing & 50 & 58.14 & 36 & 41.86 & 86 & 100.0 & \\
\hline Mobility & 19 & 86.36 & 3 & 13.64 & 22 & 100.0 & \\
\hline Multiple & 44 & 60.27 & 29 & 39.73 & 73 & 100.0 & \\
\hline \multicolumn{8}{|l|}{ Gender } \\
\hline M & 119 & 88.15 & 16 & 11.85 & 135 & 100.0 & $<0.01^{\mathrm{a}}$ \\
\hline $\mathrm{F}$ & 46 & 28.40 & 116 & 71.60 & 162 & 100.0 & \\
\hline \multicolumn{8}{|l|}{ Age (years) } \\
\hline $21-60$ & 21 & 33.33 & 42 & 66.67 & 63 & 100.0 & $<0.01^{\mathrm{b}}$ \\
\hline $61-68$ & 35 & 57.38 & 26 & 42.62 & 61 & 100.0 & \\
\hline $69-73$ & 32 & 56.14 & 25 & 43.86 & 57 & 100.0 & \\
\hline $74-79$ & 41 & 69.49 & 18 & 30.51 & 59 & 100.0 & \\
\hline $80-97$ & 36 & 63.16 & 21 & 36.84 & 57 & 100.0 & \\
\hline \multicolumn{8}{|l|}{ Family head's income $e^{\mathrm{c}, \mathrm{d}}$} \\
\hline$<1$ & 100 & 54.95 & 85 & 45.05 & 182 & 100.0 & $>0.05^{\mathrm{b}}$ \\
\hline 1 & 19 & 54.29 & 16 & 45.71 & 35 & 100.0 & \\
\hline $2-4.99$ & 20 & 50.00 & 20 & 50.00 & 40 & 100.0 & \\
\hline $5-7.99$ & 12 & 63.16 & 7 & 36.84 & 19 & 100.0 & \\
\hline$>8$ & 14 & 70.00 & 6 & 30.00 & 20 & 100.0 & \\
\hline \multicolumn{8}{|l|}{ Ethnicity $^{\mathrm{e}}$} \\
\hline Caucasian & 101 & 56.42 & 78 & 43.58 & 179 & 100.0 & $>0.05^{\mathrm{a}}$ \\
\hline Blacks/Mulattoes & 59 & 55.14 & 48 & 44.86 & 107 & 100.0 & \\
\hline Others & 4 & 44.44 & 5 & 55.56 & 9 & 100.0 & \\
\hline \multicolumn{8}{|c|}{ Use of health service during the last year } \\
\hline No & 25 & 56.82 & 19 & 43.18 & 44 & 100.0 & $>0.05^{\mathrm{a}}$ \\
\hline Yes & 140 & 55.34 & 113 & 44.66 & 253 & 100.0 & \\
\hline \multicolumn{8}{|c|}{$\begin{array}{l}\text { Assistance required to bath and dress, } \\
\text { eat, get up and/or walk }\end{array}$} \\
\hline No & 138 & 52.67 & 124 & 47.33 & 262 & 100.0 & $<0.01^{\mathrm{a}}$ \\
\hline Yes & 27 & 77.14 & 8 & 22.86 & 35 & 100.0 & \\
\hline \multicolumn{8}{|l|}{ Private health insurance } \\
\hline No & 115 & 56.93 & 87 & 43.07 & 202 & 100.0 & $>0.05^{\mathrm{a}}$ \\
\hline Yes & 50 & 52.63 & 45 & 47.37 & 95 & 100.0 & \\
\hline \multicolumn{8}{|c|}{ Coverage by a family-health program } \\
\hline No & 150 & 56.39 & 116 & 43.61 & 266 & 100.0 & $>0.05^{\mathrm{a}}$ \\
\hline Yes & 15 & 48.39 & 16 & 51.61 & 31 & 100.0 & \\
\hline
\end{tabular}

${ }^{\mathrm{a}} \chi^{2}$-test; ${ }^{\mathrm{b}} \chi^{2}$-test for trend; ${ }^{\mathrm{c}} 1$ missing case; ${ }^{\mathrm{d}}$ monthly minimum wage; ${ }^{\mathrm{e}} 2$ missing cases

cancer screening comprised persons whose family heads earn 8 or more times the monthly minimum wage (30\%).

Regarding ethnicity, the prevalence of cancer screening performed was $43.58 \%$ among Caucasians, $44.86 \%$ among Blacks or Mulattoes and $55.56 \%$ among other ethnicities.
The comparison between those who used the health service during the study period and those who did not shows that the percentages of cancer-screening procedures according to use of health service in the last year were $44.66 \%$ and $43.18 \%$, respectively. $22.88 \%$ of people with disabilities who needed help to bathe and dress, eat, 
get up, and walk participated in cancer screening, while $47.33 \%$ of those that did not need help had the same procedures.

Regarding the use of private health insurance, $43.07 \%$ of those who lacked health insurance participated in screening, and $47.37 \%$ of the persons with disabilities and health insurance attended the screening exams. Among those covered by the family health program, the percentage of cancer screening exams was $51.61 \%$ compared to $43.16 \%$ among those who did not use the program

Table 2 shows the OR of the bivariate logistic model and of the full regression model. Variables associated with attending cancer-screening programs were: disability, gender, quintiles of age, family head's income, private health insurance, and assistance required to bathe and dress, eat, get up, and walk. Persons with mobility disability had the lowest rate of cancer screening. Persons with multiple disabilities had 3.17 times more screening procedures; persons with hearing disabilities, 3.56 times more procedures; and persons with visual disabilities reported the highest frequency of procedures - 6.79 times more - always compared with persons with mobility disabilities.

A large gender difference was detected. Women had 17.75 times more screening procedures than men.

Family head's income did not show a defined pattern in cancer screening. Persons who lived in families whose heads earned between 2 and 4.99 times the monthly minimum wage had more screening procedures than others, and persons who lived in families whose heads earned at least 8 times the monthly minimum wage had fewer preventive exams.

Controlling for confounding variables (family head's income, private health insurance, and assistance required), the statistical significance ( $\mathrm{p}$

Table 2. Odds Ratio (OR) from bivariate analysis and final logistic regression model from the participation on cancer screening exams according to demographic characteristics and private health insurance, AceSS, São Paulo, 2007.

\begin{tabular}{|c|c|c|c|c|c|c|}
\hline Variables & $\mathrm{OR}^{\mathrm{a}}$ & CI $(95 \%)$ & p & $\mathrm{OR}^{\mathrm{b}}$ & CI $(95 \%)$ & $\mathbf{p}$ \\
\hline \multicolumn{7}{|l|}{ Disability } \\
\hline Visual & 7.79 & $2.18-27.79$ & $<0.01$ & 5.00 & $1.05-23.67$ & $<0.05$ \\
\hline Hearing & 4.56 & $1.25-16.57$ & $<0.05$ & 5.91 & $1.23-28.32$ & $<0.05$ \\
\hline Mobility & 1.00 & & & & & \\
\hline Multiple & 4.17 & $1.13-15.38$ & $<0.05$ & 3.75 & $0.76-18.32$ & (a) \\
\hline \multicolumn{7}{|l|}{ Gender } \\
\hline M & 1.00 & & & & & \\
\hline $\mathrm{F}$ & 18.75 & $10.0-34.9$ & $<0.01$ & 20.24 & $10.00-40.80$ & $<0.01$ \\
\hline \multicolumn{7}{|l|}{ Age (years) } \\
\hline $21-60$ & 3.42 & $1.61-7.26$ & $<0.01$ & 4.04 & $1.47-11.12$ & $<0.01$ \\
\hline $61-68$ & 1.27 & $0.60-2.66$ & (a) & 2.13 & $0.77-5.84$ & (a) \\
\hline $69-73$ & 1.33 & $0.63-2.83$ & (a) & 1.62 & $0.61-4.29$ & (a) \\
\hline $74-79$ & 0.75 & $0.34-1.62$ & (a) & 0.76 & $0.29-2.00$ & (a) \\
\hline $80-97$ & 1.00 & & & & & \\
\hline \multicolumn{7}{|c|}{ Family head's income $e^{c, d}$} \\
\hline$<1$ & 1.91 & $0.70-5.20$ & (a) & 1.66 & $0.48-5.66$ & (a) \\
\hline 1 & 1.96 & $0.61-6.29$ & (a) & 1.80 & $0.41-7.71$ & (a) \\
\hline $2-4.99$ & 2.33 & $0.74-6.29$ & (a) & 3.52 & $0.83-14.81$ & (a) \\
\hline $5-7.99$ & 1.36 & $0.35-5.67$ & (a) & 1.12 & $0.19-6.35$ & (a) \\
\hline$>8$ & 1.00 & & & & & \\
\hline \multicolumn{7}{|c|}{ Private health insurance } \\
\hline No & 1.00 & & & 1.00 & & \\
\hline Yes & 1.18 & $0.72-1.94$ & (a) & 1.71 & $0.86-3.40$ & (a) \\
\hline \multicolumn{7}{|l|}{ Assistance required ${ }^{e}$} \\
\hline No & 1.00 & & & 1.00 & & \\
\hline Yes & 0.32 & $0.14-0.75$ & $<0.01$ & 0.50 & $0.17-1.48$ & (a) \\
\hline
\end{tabular}

Source: Novaes et al. ${ }^{35}$

(a) $5 \%<\mathrm{p}<20 \%$; ${ }^{a}$ bivariate analysis with logistic regression model; ${ }^{\mathrm{b}}$ adjusted for all variables from the logistic regression model; ${ }^{\mathrm{c}}$ monthly minimum wage; ${ }^{\mathrm{d}} 1$ missing case; ${ }^{\mathrm{e}}$ Help required to bathe and dress, eat, get up and/or walk. 
$<0.05$ ) persisted for disability (visual or hearing disability as compared to mobility), gender and quintiles of age (from 21 to 60 years old compared with persons between 80 and 97 years old).

After all adjustments in the logistic regression model had been performed, persons with visual disabilities had 4 times more screening exams than persons with mobility disabilities, and persons with hearing disabilities had 4.91 times more preventive exams than those with mobility disabilities. Women had 19.24 times more exams than men, and persons between 21 and 60 years old had 3.04 times more exams than those between 80 and 97 years old.

\section{Discussion}

The results of this research showed a $44.44 \%$ prevalence of cancer screening among persons with disabilities. Since São Paulo now has approximately 11 million inhabitants, and nearly $11.8 \%$ of its total population has one or more disabilities $^{9}$, this figure represents almost 1.2 million people. Applying this rate of cancer-screening procedures, 670,000 persons with disabilities had some form of cancer screening exam. Although everyone should participate in cancer screening, as this investigation shows, not everyone has access to them. This is surprising, since Brazil has a free public-health system which, according to the National Health Policy for Persons with Disabilities $^{15}$, applies to persons with disabilities. In São Paulo, the General Guidelines for the Health Care of Persons with Disabilities ${ }^{16}$ also guarantees and supports the right to full health care provided by the federal policy.

The percentage of women with disabilities who had a Pap smear $(65.11 \%)$ was close to that among women in the Brazilian general community $(65.00 \%)^{17}$ and lower than that among the women from São Paulo city $(90.30 \%)^{18}$. The rate from the persons with disabilities that reported the Pap smear in this study is higher than those reported to the Pernambuco state $(58.5 \%)^{19}$, Estonia $(44.1 \%)^{20}$, Buenos Aires city $(31.0 \%)^{21}$ and to Greece $(41.1 \%)^{22}$. However, the percentage of Pap smear among women with disabilities was lower than that from Rio de Janeiro city $(83.5 \%)^{23}$, Puerto Rico $(71.9 \%)^{24}$, USA $(84.0 \%)^{25}$ and from Austria $(83.0 \%)^{22}$.

Regarding to the mammography, women with disabilities had a higher percentage (53.52\%) than women in the Brazilian general community $(47.2 \%)^{17}$, Porto Velho $(41.2 \%)^{26}$ and Campinas
$(49.2 \%)^{27}$ cities, Korea $(30.4 \%)^{28}$ and CataloniaSpain $(40.39 \%)^{29}$. But the percentage is lower than those from the general populatoin in São Paulo city $(82.10 \%)^{18}$, Porto Alegre $(75.7 \%)$ and Florianópolis $(82.2 \%)$ cities $^{26}$.

Men with disabilities had more prostate cancer screening (75.94\%) than men in the general population of Southern Brazil $(22.5 \%)^{30}$, São Paulo city $(55.30 \%)^{18}$, USA $(52.0 \%)^{31}$, Canada $(35.0 \%)^{32}$ and Croatia $(13.7 \%)^{33}$.

The rectal cancer screening rates among persons with disabilities $(13.0 \%)$ were higher than those in the general population from São Paulo city $(12.20 \%)^{18}$ and lower that the reported for U.S. citizens ${ }^{34}(26.0 \%$ - faecal occult blood testing and $33.0 \%$ - sigmoidoscopy), Korean $(36.6 \%)^{35}$ and Canadian $(30.1 \%)^{36}$ citizens.

Factors related to the rate of cancer screening have been widely reported. Among women, factors like age ${ }^{37,38}$, marital status ${ }^{39,40}$, family income $^{41}$, ethnicity ${ }^{17}$, social status ${ }^{42}$, use of publichealth services ${ }^{43}$, use of health services in the last year ${ }^{43}$, functional limitations ${ }^{44}$, and number of households members ${ }^{45}$ are mentioned. The studies with male samples, although less frequent, reported education ${ }^{46}$, ethnicity ${ }^{47}$, age ${ }^{48,49}$ poorer medical-insurance coverage ${ }^{50}$, use of public-health services $^{50}$, and family income ${ }^{51}$ as factors influencing participation in cancer screening programs.

The analysis reported here also shows relationships among selected social variables and cancer screening among people with disabilities. While the family head's income, ethnicity, use of health services in the last year, and coverage by a familyhealth program were not statistically significant, disability, gender, quintiles of age, and the assistance required to bathe and dress, eat, get up and walk reached the 5\% significance level. The variables family head's income, private health insurance, and assistance required were used for adjustment, i.e., these three variables had no influence on the dependent variable, although they should be considered due to their indirect influence on participation in cancer-screening programs. After adjustment, disability, quintiles of age and gender were still significant, showing a direct relationship with the screening procedures used.

Persons with mobility disabilities (paralysis or amputation) was the group with the lowest participation in cancer screening compared to persons with visual or hearing disabilities. This low participation among persons with mobility disabilities might be compared to the accessibility problems experienced by persons with paralysis or amputation ${ }^{52}$. Importantly, women had more 
screening exams than men, which conflicts with the literature ${ }^{53}$, which reports the opposite. For elderly persons in the US, men had more cancerscreening exams than women, and the decline with age was greater for women ${ }^{53}$. There is, therefore, a difference in patterns of cancer screening between men and women that further distinguishes people with and without disabilities.

There were more people aged between 21 and 60 that had preventive cancer exams than those between 80 and 97 years. This may be the result of health campaigns on cancer screening that reach a younger population more readily than an older one. The fact that younger people have better access to health information than the elderly may explain this difference. The internet may account for easy access to information by younger persons ${ }^{54}$.

A limitation of this study is that it is only exploratory and relies exclusively on cross-sectional data, identifying only association and the direction of association cannot be determined. A study with a larger sample needs to be conducted to confirm these results. Another limitation is that the data collected was self-reported, and confirmation of the screening exam by objective means, such as medical forms, and clinical assessment of reported disabilities by clinical examinations, would also improve the study. Recall bias and the report of Pap smear when in fact the women only had a pelvic exam ${ }^{55}$ could be another weakness of this research.

The characteristics of people with disabilities linked to whether or not cancer screening was performed presented here are different from those already reported in the literature. Type of disability, gender, and age are directly associated with participation in screening programs, while family head's income, private health insurance, and the assistance required to bathe and dress, eat, get up, and/or to walk had only indirect influence and were, therefore, confounding factors.
The others variables studied were not statistically related to screening (ethnicity, use of health services in the last year, and coverage by the family health program).

The findings may be useful for the delineation and planning of health policies and programs for cancer prevention among persons with disabilities, as the study indicates that persons with disabilities have a different participation profile. Thus, specific health measures could be planned for this population group to increase the early detection of cancer and assistance offered by the health services.

\section{Collaborations}

SS Castro worked in the design, planning, data collection, monitoring, analysis and writing of the manuscript. A Cieza and CLG Cesar participated in the review and drafting of the paper.

\section{Acknowledgement}

We thank Professor Jerome Bickenbach for his helpful comments and review of the final manuscript. 


\section{References}

1. Micheli A, Coebergh JW, Mugno E, Massimiliani E, Sant M, Oberaigner W, Holub J, Storm HH, Forman D, Quinn M, Aareleid T, Sankila R, Hakulinen T, Faivre J, Ziegler H, Tryggvadòttir L, Zanetti R, Dalmas M, Visser O, Langmark F, Bielska-Lasota M, Wronkowski Z, Pinheiro PS, Brewster DH, Plesko I, Pompe-Kirn V, Martinez-Garcia C, Barlow L, Möller T, Lutz JM, André M, Steward JA. European health systems and cancer care. Ann Oncol 2003; 14(Supl. 5):41-60.

2. Brasil. Ministério da Saúde (MS). Datasus. Informações de saúde. [página na Internet]. [acessado 2013 out 8]. Disponível em: http://tabnet.datasus.gov.br/ cgi/deftohtm.exe?sih/cnv/nrsp.def

3. Instituto Nacional do Câncer (INCA). Vigilância do câncer e fatores de risco. Atlas de mortalidade por câncer. [página na Internet]. [acessado 2013 out 8]. Disponível em: http://mortalidade.inca.gov.br/ ?saude $=$ http $\% 3 \mathrm{~A} \% 2 \mathrm{~F} \% 2 \mathrm{Fmortalidade}$.inca.gov.br\& botaook=OK\&obj=http\%3A\%2F\%2Fmortalidade.inca. gov.br

4. Bastos J, Peleteiro B, Gouveia J, Coleman MP, Lunet $\mathrm{N}$. The state of the art of cancer control in 30 European countries in 2008. Int J Cancer 2010; 126(11):2700-2715.

5. World Health Organization (WHO). Cytological screening in the control of cervical cancer: technical guidelines. Genebra: WHO; 1988.

6. Sclowitz ML, Menezes AMB, Gigante DP, Tessaro S. Condutas na prevenção secundária do câncer de mama e fatores associados. Rev Saude Publica 2005; 39(3):340-349.

7. Tucunduva LTCM, Sá VHLC, Koshimura ET, Prudente FVB, Santos AF, Samano EST, Costa LSM, Del Giglio A. Estudo da atitude e do conhecimento dos médicos não oncologistas em relação às medidas de prevenção e rastreamento do câncer. Rev. Assoc. Med. Bras. 2004; 50(3):257-262.

8. Instituto Nacional de Câncer (INCA). Prevenção e controle do câncer. Rev Bras Cancerologia 2002; 48(3):317-333.

9. Castro SS, César CLG, Carandina L, Barros MBA, Alves MCGP, Goldbaum M. Deficiência visual, auditiva e física: prevalência e fatores associados em estudo de base populacional. Cad Saude Publica 2008; 24(8):1773-1782.

10. Castro SS, César CLG, Carandina L, Barros MBA, Alves MCGP, Goldbaum M. Physical Disability, Recent Illnesses and Health Self-Assessment in a Population-Based Study in São Paulo, Brazil. Disabil \& Rehabil 2010; 32(19):1612-1615.

11. Tejeda S, Thompson B, Coronado GD, Martin DP. Barriers and facilitators related to mammography use among lower educated Mexican women in the USA. Soc Sci Med 2009; 68(5):832-839.

12. Ramirez A, Farner GC, Grant D, Papachristou T. Disability and preventive cancer screening: results from the 2001 California Health Survey. Am J Public Health 2005; 95(11):2057-2064.
13. Universidade de São Paulo (USP). Faculdade de Saúde Pública (FSP). Inquéritos de saúde em São Paulo. [página na Internet]. [acessado 2013 out 8]. Disponível em: http://www.fsp.usp.br/isa-sp

14. Gimeno SGA, Souza JMP. Using of stratification and the logistic regression model in the analysis of data of case-control studies. Rev Saude Publica 1995; 29(4):283-289.

15. Brasil Ministério da Saúde (MS). Política Nacional de Saúde da pessoa com deficiência. [página na Internet]. 2009 [acessado 2013 set 29]. Disponível em: http://portal. saude.gov.br/portal/arquivos/pdf/ Cart09.pdf

16. São Paulo (Cidade). Secretaria Municipal de Saúde. Coordenação da Atenção Básica. Área Técnica da Saúde da Pessoa com Deficiência. Diretrizes técnicas para gestores e profissionais na área da Saúde da pessoa com deficiência- 2011; 141p. [acessado 2013 jul 25]. Disponível em: http://www. prefeitura.sp.gov.br/cidade/secretarias/upload/ saude/arquivos/deficiencia/COT-2011.pdf

17. Leal MC, Gama SGN, Frias P, Szwarcwald CL. Healthy lifestyles and access to periodic health exams among Brazilian women. Cad Saude Publica 2005; 21(Supl. 1):S78-S88

18. Prefeitura de São Paulo. Secretaria Municipal da Saúde. Coordenação de Epidemiologia e Informação - CEInfo. Boletim ISA - Capital 2008, no 3, 2010: Inquérito de Saúde, Exames Preventivos. São Paulo: CEInfo; 2010.

19. Albuquerque KM, Frias PG, Andrade CLT, Aquino EML, Menezes G, Szwarcwald CL. Pap smear coverage and factors associated with non-participation in cervical cancer screening: an analysis of the Cervical Cancer Prevention Program in Pernambuco State, Brazil. Cad Saude Publica 2009; 25(Supl. 2): s301-s309.

20. Tekkel M, Veideman T, Baburin A, Rahu M. Use of mammography and Pap smear in Estonia, a country without organized cancer screening. Int J Public Health 2007; 52(2):109-116.

21. Arrossi S, Ramos S, Paolino M, Sankaranarayanan R. Social inequality in Pap smear coverage: identifying under-users of cervical cancer screening in Argentina. Reprod Health Matters 2008; 16(32):5058.

22. Palència L, Espelt A, Rodríguez-Sanz M, Puigpinós R, Pons-Vigués M, Pasarín MI, Spadea T, Kunst AE, Borrell C. Socio-economic inequalities in breast and cervical cancer screening practices in Europe: influence of the type of screening program. Int $J$ Epidemiol 2010; 39(3):757-765.

23. Martins LFL, Valente JG, Thuler LCS. Factors related to inadequate cervical cancer screening in two Brazilian state capitals. Rev Saude Publica 2009; 43(2):318-325. 
24. Ortiz AP, Hebl S, Serrano R, Fernandez ME, Suárez E, Tortolero-Luna G. Factors associated with cervical cancer screening in Puerto Rico. Prev Chronic Dis 2010; 7(3):A58.

25. Nelson W, Moser RP, Gaffey A, Waldron W. Adherence to cervical cancer screening guidelines for U.S. women aged 25-64: data from the 2005 Health Information National Trends Survey (HINTS). $J$ Womens Health (Larchmt) 2009; 18(11):1759-1768.

26. Viacava F, Souza-Junior PRB, Moreira RS. Estimates of mammography coverage according to health surveys in Brazil. Rev Saude Publica 2009; 43(Supl. 2):117-125.

27. Amorim VMSL, Barros MBA, Cesar CLG, Carandina L, Goldbaum M. Factors associated with women's failure to submit to Pap smears: a population-based study in Campinas, São Paulo, Brazil. Cad Saude Publica 2006; 22(11):2329-2338.

28. Lee K, Lim HT, Park SM. Factors associated with use of breast cancer screening services by women aged $>$ or $=40$ years in Korea: the third Korea national health and nutrition examination survey 2005 (KNHANES III). BMC Cancer 2010; 10:144.

29. Masuet C, Seculi E, Brugulat P, Tresseras R. La práctica de la mamografía preventiva en Cataluña: Un paso adelante. Gac Sanit 2004; 18(4):321-325.

30. Mendoza-Sassi R, Beria JU. Prevalence of having a regular doctor, associated factors, and the effect on health services utilization: a population-based study in Southern Brazil. Cad Saude Publica 2003; 19(5):1257-1266.

31. Hoffman KE, Nguyen PL, Ng AK, D’Amico AV. Prostate cancer screening in men 75 years old or older: an assessment of self-reported health status and life expectancy. J Urol 2010; 183(5):1798-1802.

32. Strumpf EC, Chai Z, Kadiyala S. Adherence to cancer screening guidelines across Canadian provinces: an observational study. BMC Cancer 2010; 10:304.

33. Polasek O, Kolcic I, Voncina L, Strnad M, Vuletic S, Kern J. Breast, colon, and prostate screening in the adult population of Croatia: does rural origin matter? Rural Remote Health 2007; 7(3):749.

34. Vernon SW. Participation in Colorectal Cancer Screening: a Review. J of the Nation Cancer Institute 1997; 89(19):1406-1422.

35. Choi KS, Jun JK, Lee HY, Hahm MI, Oh JH, Park EC. Increasing uptake of colorectal cancer screening in Korea: a population-based study. BMC Public Health 2010; 10:265.

36. Sewitch MJ, Fournier C, Ciampi A, Dyachenko A. Colorectal cancer screening in Canada: results of a national survey. Chronic Dis Can 2008; 29(1):9-21.

37. Novaes HMD, Braga PE, Schout D. Fatores associados à realização de exames preventivos para câncer nas mulheres brasileiras, PNAD 2003. Cien Saude Colet 2006; 11(4):1023-1035.
38. Amorim VMSL, Barros MBA, César CLG, Carandina $\mathrm{L}$, Goldbaum M. Fatores associados a não realização da mamografia e do exame clínico das mamas: um estudo de base populacional em Campinas, São Paulo, Brasil. Cad Saude Publica 2008; 24(11):2623-2632.

39. Achat H, Close G, Taylor R. Who has regular mammograms? Effects of knowledge, beliefs, socioeconomic status, and health-related factors. Prev Med 2005; 41(1):312-320.

40. Feitosa RCL, Pontes ERJC. Levantamento dos hábitos de vida e fatores associados à ocorrência de câncer de tabagistas do município de Sidrolândia (MS, Brasil). Cien Saude Colet 2011; 16(2):605-613.

41. Matejic B, Vukovic D, Pekmezovic T, Kesic V, Markovic M. Determinants of preventive health behavior in relation to cervical cancer screening among the female population of Belgrade. Health Educ Res 2011; 26(2):201-211.

42. Muller DK, Dias-da-Costa JS, Luz AMH, Olinto MTA. Cobertura do exame citopatológico do colo do útero na cidade de São Leopoldo, Rio Grande do Sul, Brasil. Cad Saude Pública 2008; 24(11):2511-2520.

43. Sclowitz ML, Menezes AMB, Gigante DP, Tessaro S. Condutas na prevenção secundária do câncer de mama e fatores associados. Rev Saude Publica 2005; 39(3):340-349.

44. Schootman M, Jeffe DB. Identifying factors associated with disability-related differences in breast cancer screening (United States). Cancer Causes and Control 2003; 14(2):97-107.

45. Amorim VMSL, Barros MBA, César CLG, Carandina L, Goldbaum M. Fatores associados à não realização do exame de Papanicolaou: um estudo de base populacional no Município de Campinas, São Paulo, Brasil. Cad Saude Publica 2006; 22(11):2329-2338.

46. Carpenter WR, Godley PA, Clark JA, Talcott JA, Finnegan T, Mishel M, Bensen J, Rayford W, Su J, Fontham ETH, Mohler JL. Racial differences in trust and regular source of patient care and the implications for prostate cancer screening use. Cancer 2009; 115(21):5048-5059.

47. Consedine NS, Morgenstern AH, Kudadjie-Gyamfi E, Magai C, Neugut AL. Prostate Cancer Screening Behavior in Men from Seven Ethnic Groups: the Fear Factor. Cancer Epidemiol Biomarkers Prev 2006; 15(2):228-237.

48. Miranda PSC, Côrtes MCJW, Martins ME, Chaves PC, Santarosa RC. Práticas de diagnóstico precoce de câncer de próstata entre professores da faculdade de medicina - UfMG. Rev. Assoc. Med. Bras. 2004; 50(3):272-275

49. Gonçalves IR, Padovani C, Popim RC. Caracterização epidemiológica e demográfica de homens com câncer de próstata. Cien Saude Colet 2008; 13(4):13371342 . 
50. Talcott JA, Spain P, Clark JA, Carpenter WR, Do YK, Hamilton RJ, Galanko JA, Jackman A, Godley PA. Hidden barriers between knowledge and behaviour: the North Carolina prostate cancer screening and treatment experience. Cancer 2007; 109(8):1599-1606.

51. Amorim VMSL, Barros MBA, César CLG, Goldbaum M, Carandina L, Alves MCGP. Fatores associados à realização dos exames de rastreamento para o câncer de próstata: um estudo de base populacional. Cad Saude Publica 2011; 27(2):347-356.

52. Mele N, Archer J, Pusch BD. Access to breast cancer screening services for women with disabilities. $J$ Obstet Gynecol Neonatal Nurs 2005; 34(4):453-464.

53. McFall SL, Davila M. Gender, social ties, and cancer screening among elderly persons. J Aging and Health 2008; 20(8):997-1011.

54. Lorence D, Park H. Group disparities and health information: a study of online access for the underserved. Health Informatics J 2008; 14(1):29-38.

55. Chan L, Doctor JN, MacLehose RF, Lawson H, Rosenblatt RA, Baldwin LM, Jha A. Do Medicare patients with disabilities receive preventive services? A population-based study. Arch Phys Med Rehabil. 1999; 80(6):642-646.

Artigo apresentado em 31/08/2012

Aprovado em 27/11/2012

Versão final apresentada em 10/12/2012 